practice see all the details of the fluorescent-screen picture. The presbyopic men must use their glasses for near vision. Secondly, it is contended that operations with the screen are dangerous. The obvious answer is thiot if any $X$ ray room is dangerons, then the radiologist is very blameworthy in not having tested its safety and remedied it, while he is the person who is by far the most likely to suffer. A third objection is that asepsis cannot be maintained. It certainly can be. The direct control cases did better than the ordinary operating theatre ones in our experience. Besides, the $\mathrm{X}$ ray room, with nitrogen peroxides from electric discharges always in evidence, is a spot not favourable to pathogenic germgrowth. The final argument that there is no real necessity for direct control operations is quite untenable. Five years military hospital experience of much-operated-on patients still carrying their shell fragments unfortunately proved their necessity.

Summary.

(1) The removal of foreign bodies by preliminary mutual consultation, followed by an operation under direct $X$ ray control has been, and will still be in the future, a necessity in certain cases. (2) A direct $X$ ray control operation can be carried out successfully with ordinary equipment. (3) The after-results of such an operation are found to be satisfactory. (4) The practice of direct $\bar{X}$ ray control operations for the removal of metallic foreign bodies is one to be recommended in general, and especially will be required so long as cases remain who present disability due to their continued presence.

\section{olliniral 嗮otes:}

\section{MEDICAL, SURGICAL, OBSTETRICAL, AND THERAPEUTICAL.}

\section{INFECTION WITH THE ORGANISMS VINCENT'S ANGINA FOLLOWING MAN.BITE.}

By P. H. Hennessy, M.B., C.M. Madras,

MEDICAL OFFICER IN CHARGE, GENERAL HOSPITAX, KUALA LUMPUR; AND

WILLIAM FreTCHER,

PATHOLOGIST, INSTITUTE FOR MEDICAL RESEARCH, KUALA LUMPUR, FEDERATED MALAY STATES.

Many years ago Babes, Plaut, Vincent, and others described a disease which usually begins as an acute stomatitis or tonsillitis, and may lead to the formation of a membrane resembling diphtheria. In the lesions they found spindle-shaped or fusiform bacilli associated with spirochætes. This disease is now known as Vincent's angina. Taylor and McKinstry, ${ }^{1}$ who investigated its occurrence amongst soldiers, found that the characteristic lesions were always preceded by a localised, peridental, or marginal gingivitis. More recently Semple and others, ${ }^{2}$ as the result of the examination of a large number of persons, concluded that fusiform bacilli and spirochætes are normal inhabitants of the healthy buccal cavity.

The occurrence of these organisms is not limited to the mouth and throat. Vincent found fusiform bacilli, together with spirochætes, in hospital gangrene, and in 1896, at the Académie de Médecine, he stated that they were the cause of tropical phagedæna. They have been found in noma and in erosive balanitis and vulvitis. Dick ${ }^{3}$ has reported the presence of fusiform bacilli in three cases of meningitis in which the infection probably arose from the middle ear. Heyde, ${ }^{6}$ in an examination of 102 cases of appendicitis, found fusiform bacilli in 8. Luger ${ }^{7}$ has found spirochretes and fusiform bacilli in the stools. Peters ${ }^{4}$ found them in a case of lung abscess and in another of foetid bronchitis. Recently Blanchard ${ }^{8}$ described a number of cases of phagedæna complicating vaccination pustules, which was due to spirochætes and fusiform bacilli.

The infection of wounds caused by the teeth has been reported by Peters. ${ }^{4}$ In one instance a labourer injured his fingers by striking a man in the mouth. The injury was followed by intense swelling, oedema, and a foul discharge in which fusiform bacilli were discovered in association with streptococci, but without spirochætes. The same author describes the case of a bar-tender who hit a man in the mouth and injured his own hand. Despite free incisions and soaking in antiseptic lotions there was deep destruction of tissue and the hand did not heal for 54 days. In this instance great numbers of spirochætes were associated with.the fusiform bacilli. Peters also mentions the case of a 7-year-old child who suffered from partial gangrene of one of her index fingers as the result of infection with spirochætes and fusiform bacilli attributed to the child's habit of biting her nails with her carious teeth.

\section{Details of Case.}

Our patient, C. P., a Tamil, was in charge of a small plantation where, one day, he caught a Malay stealing some of the rubber crop. The Malay fought savagely, bit the Tamil severely in the forearm, and then seized his left thumb between his teeth and bit it with such force that the nail was torn off and the terminal phalanx was fractured. When the patient was admitted to hospital in Kuala Lumpur a fortnight after the fight, the whole thumb was

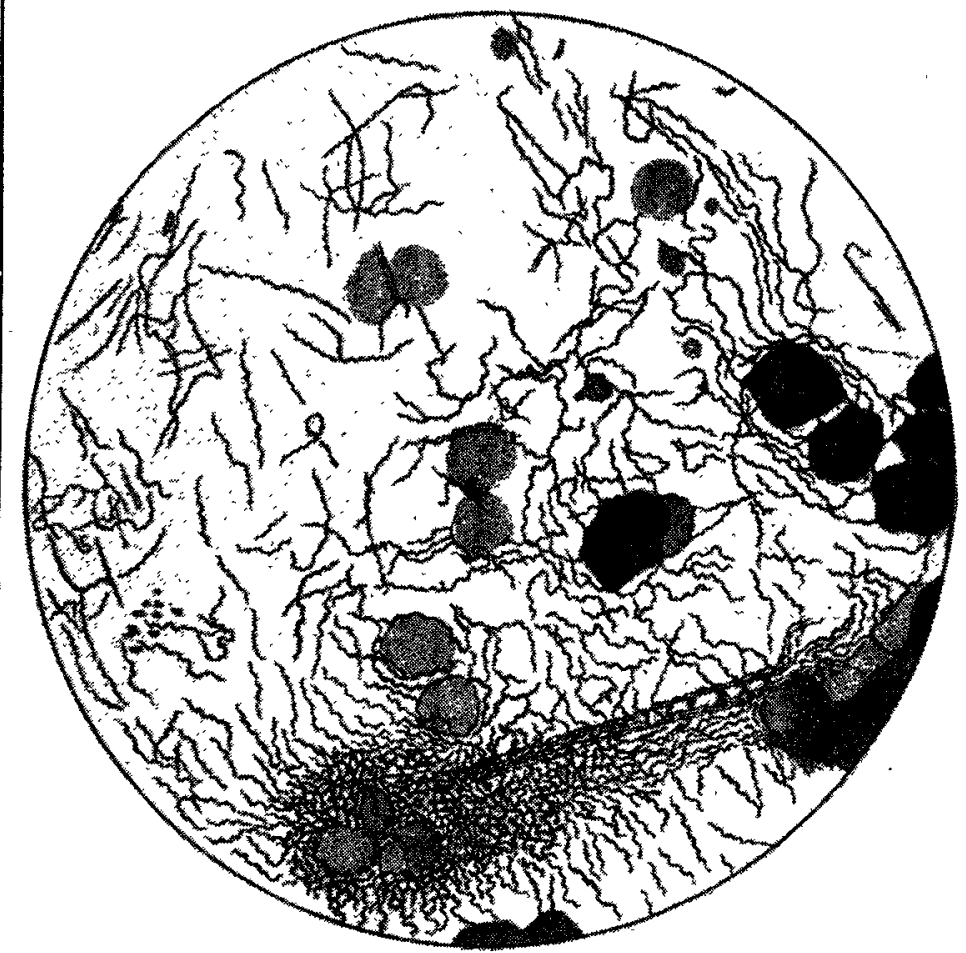

Pus film from the patient's thumb. Stained by Fontana's method. There were very few fusiform bacilli in this film.

swollen and indurated; where the nail should have been there was only a soft mass of granulation tissue with sinuses leading down to the fractured phalanx, and at the base of the thumb there was an abscess which involved the metacarpo-phalangeal joint. The patient's temperature was slightly raised, but it fell to normal when the abscess was opened.

The pus from the sinuses contained fusiform bacilli and normous numbers of spirochntes in writhing, tangled masses. These spirochætes were of several types and sizes. At one end of the scale there were large, actively motile organisms of the refringens type, which probably corresponded with Semple's Spironema buccale, and at the other end there were very minute active spirochætes, smaller than $S$. pallialum, but with the same regular coils. Between these extremes there were two other forms which were probably the same as those described by Semple under the names of S. medium and S. dentium.

Tubes of serum agar were inoculated by introducing plugs of cotton-wool, which had been soaked in the discharge, into the bottom of the medium (as recommended by Semple), and a growth of spirochætes was obtained in mixed culture. Fusiform bacilli were also grown from the discharge by the method of Krumwiede and Pratt.

Inoculations with the discharge from the thumb were made subcutaneously and into the testes of a rabbit, but it remaine 1 healthy The experience of others has been this same; Blanchard, ${ }^{9}$ for instance, found that the organisms of Vincent's angina do not multiply when they are inoculated under the healthy skin but only after it has been injured, as, for example, by an escharotic, such as caustic potash.

Vincent's angina does not cause a positive Wassermann reaction. In our case the patient's serum gave a slight positive reaction, but this was probably due to syphilis, for he admitted that he had suffered from a chancre ten years before.

Louis Rousseau ${ }^{10}$ states that tropical phagedænism due to spirochætes and fusiform bacilli can be cured in about a week by three injections of $0.3 \mathrm{~g}$. of novarsenobillon given on the flrst, fourth, and seventh 
days. In our patient the thumb-joints were disorganised, the phalanges and the distal end of the metacarpal bone were necrotic; the disease had gone too far, and the pain was so severe that amputation was imperative. The patient was given two injections of $0.6 \mathrm{~g}$., and after the operation he made an excellent recovery.

The main feature of this case and of that reported by Peters, is the widespread destruction of tissue (which in our patient involved the bones), resulting from an infection with spirochætes and fusiform bacilli.

References. - I. Jour. R.A.M.C., 1918, p. 512 2. Ibid., October, 1919, 3. Jotr. xii, p 199, 6. Ztsche f klin Chir, 1911, ix., p. 455. 5. Ibid. Med. Science, March, 1920, p. 589. 8. Bull. Soc. Path. Exotique, 1919, p. 493. 9. Ibid., 1914, p. 96 . 10. Ibid.. 1919. 1). 495

\section{A CASE OF PHOCOMELUS.}

By Cawas Homr, M.B., B.S. Bombat, M.R.C.S., ENG., L.R.C.P. LOND.

THIs type of monstrosity in mankind being comparatively rare, I think this case will be of interest to teratologists and the medical profession in general. Phocomelus is one of the sub-varieties of the monsters

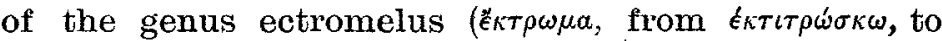
abort or miscarry, and $\mu e^{\prime} \lambda o s$, a limb), a monstrosity in which the limbs are nearly or altogether deficient from an arrest of development as distinguished from spontaneous amputation. This name was given by the celebrated anatomist, Isidore Geoffroy Saint Hilaire, in 1832, whí subdivided ectromelus into amelus, phocomelus, hemimelus, and ectrodactyly. The term amelus is restricted to the cases in which all the four limbs are absent, whilst the phocomelus foetus is one in which the proximal and not the distal segment of one or more Iimbs is aborted, thus contrasting markedly with hemiwelus, in which the distal segment is the part affected. In phocomelus the foot or hand seems to spring directly from the trunk, giving the extremity or extremities the appearance of the flippers of the seal (phoca). Eetrodactyly, a lesser degree of deformity of the genus ectromelus, shows a rudimentary hand in which the phalanges are represented by small tubercles.

Further reference to these varieties is found in Ballantyne's "Ante-Natal Pathology and Hygiene," with good illustrations and explanations. Cases of ectrodactyly are described by Dr. E. Cautley and Dr. J. D. Rolleston in the Transactions of the Royal Society of Medicine.

Description of Case.

This phocomelus child was brousht to the out-patient department of the Belgrave Hospital for Children for fits, and was admitted for obserration, I ray examination, and photograph. He was well built,

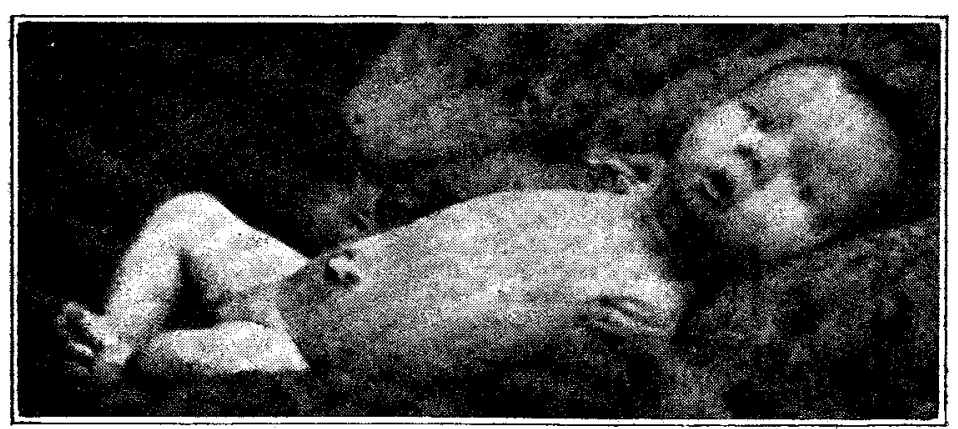

$8 \mathrm{day}$ old, and showed no associated abnomality or nalformation common in these monstrosities, such as umbilical, inguinal, or diaphragmatic hernia, cleft-palate, hare-lip, undescended testicle dextrocarda or malformation of the heart, imperforate anus spina bifida, and so forth. The umbilical cord had not yet dropped, and was black and dry. Head meastured 15 inches, and its appear ance sugsested some internal hydrocer the fits. The child cried rigorousl

On inquiry I found this monster was born as footling of healthy parents on March 24th, the mother having been in labour for eight hours. The period of gestation was estimated at 41 weeks, the Fother 42 ving had Father, 42 years old, is a sallor the mother, aged $42 \frac{1}{2}$ sears, has had three other normal healthy children (one bos and hwo sirls. ased 16. 14, and 9 years respectirely). One miscarriage in 1912 and no further deformity to her having seen, when about six weeks presnant, a discharged soldier in a fit which lasted over half an hour. She saw him lying on the ground unconscious with twitching of the face his arms addueted to his sides, forearm flexed at the elbow, and hands alternately hyperextended and flexed at the wrist. She wen to his help and tried to lift him up, but she herself was foelin bad and gidds and dropped down on the floor: she was picked up and taken to her room, where she lay ill in bed for two weeks. She had a constant dread lest she might give birth to a child who might suffer from fits like the soldier, and she would wake up a night hearing and seeing a man in a fit.

For three days after the child's birth she was very excited, disliked the baby, and did not care to feed him. When four days old the child had a fit and became very blue, so the father brought him to the hospital. The child was in the hospital for a week and had fits daily, some of them severe, prolonged, and accompanied b cyanosis. The father was told that there was no hope for the child, and took him home; and death occurred during a fit when 20 days old. Unfortunately a post-mortem examination was not obtainable.

Theories of Causation.

There have been many theories propounded as to the causation of these monstrosities. In ancient times supernatural factors were invoked; some teratologists attribute them to intra-uterine conditions, such as amniotic pressure, adhesions, bands, and intra-uterine amputation, but I am inclined to believe that the chief factor in the causation of the malformation in this case was the strong maternal impression, which led to the arrest of the ontogenesis in the embryonic and neofotal stage of existence of this child.

In conclusion, I wish to record my indebtedness to Dr. Cautley for his valuable assistance and permission to publish this case.

\section{attedical Sorieties.}

\section{ROYAL SOCIETY OF MEDICINE.}

\section{SECTION OF OBSTETRICS AND GYNACOLOGY.}

A MEETING of this section of the Royal Society of Medicine was held on July 8th, Mr. J. D. MaLcolm, the retiring President, being in the chair.

$$
\text { Exhibition of Specimens. }
$$

Dr. J. D. BARRIs showed a specimen of Primary Carcinoma of the Fallopian Tubes in a 3-para of 53. The menopause occurred three years ago and she was well till November, 1919, when she began to have repeated hamorrhages. When she was operated on in May, 1920, the uterus and ovaries were normal, but a columnar carcinoma was found in a Fallopian tube, which was so distended as to resemble a hydrosalpinx.

Dr. A. H. Richaroson showed a Fibroma of an Ovary, with warty projections, removed from a girl of 16. Its unusual feature was its warty appearance, as it was surrounded by large papillomata with fissures 1 inch to $1 \frac{1}{2}$ inches deep. On microscopic examination no signs of malignancy had been found.

\section{Mr. GORDON LEY lead a paper on}

The Pathology of Accidental Homorrhage.

The first part of his paper dealt with the literature of the subject, which he reviewed at some length. He next read pathological details of the uteri removed from three cases of accidental hæmorrhage, of the kidneys of three cases, and of the liver of two cases. He had used as controls five uteri removed ante. or post-mortem for rupture or for some condition apart from accidental hæmorkhage. He found in all uteri a leucocytic infiltration, both of the decidua and of the myometrium. This was not greater in the cases of accidental hæmorrhage than in the control uteri. He also found granules of fat in the interstitial cells of the connective tissue. These also were not more numerous in the accidental hæmomhage cases than in the control cases. He found in the cases of accidental hæmorrhage extensive albuminous cedema of the myometrium in the outer part of the wall, both of the body and of the lower uterine segment and cervix. In the control cases there was codema only of the stretched lower uterine segment. In the cases of accidental hrmorrhage there were focal areas of degeneration, necrosis, and hæmorrhage throughout the myometrium of the body, lower uterine segment, and cervix. The distribution of these areas of necrosis was such that they coula not be attributed bo the 